We thank Dr S. Anderson of the American Museum of Natural History for help and advice. This work was supported by a Research Career Development Award to A. E. D., and by the US Public Health Service and the Hartford Foundation.

Aluan E. Dumont KenNeth M. Rifkind

Department of Surgery,

New York University School of Medicine.

Received June 4, 1968

${ }^{1}$ Silvester, C. F., Amer. J. Anat.,12, 447 (1912).

2 Wislocki, G. B., J. Morphol. Physiol., 46, 317 (1928).

${ }^{3}$ Azzali, G., and Dido, L. J. A., Anat. Rec., 153, 149 (1965).

- Enelolion helvum helvum-Africa, Hippsideros armiger-Africa, Brashyphyll cavernarium-Virgin Islands, Pteropus (Flying Fox)-Madagascar.

'Darwin, C., in The Descent of Man,11, 25 (Appleton, New York, 1892).

'Blalock, A., Robinson, C. S., Cunningham, R. S., and Graz, M., Arch, Surg. 84, 1049 (1937)

${ }^{7}$ Dumont, A. E., and Mulholland, J. H., Ann. Surg., 156, 668 (1962).

${ }^{8}$ Dumont, A. E., Clauss, R., Reed, G., and Tice, D., New Engl. J. Med., 269

- Warren, M. F., and Drinker, C. K., Amer. J. Physiol., 137, 641 (1942).

\section{Carcinogenicity of Tobacco Smoke Condensate to Mouse Skin}

In his review of the recently published book Tobacco and Tobacco Smoke by Wynder and Hoffmann, Professor Passey ${ }^{1}$ draws attention to the discrepancy between results of painting cigarette smoke condensate on the skin of mice in the United States and Great Britain. Results of Wynder et $a l .{ }^{2}$, who obtained in America 44.4 per cent of skin carcinomata from a group of eighty-one mice, are compared with 3-5 per cent obtained by workers in Great Britain. Day's work is quoted in support of these low percentages ${ }^{3}$, and a figure of 3 per cent of 7,875 mice seems to confirm the apparent very low carcinogenicity. This total, however, includes 1,320 untreated controls and 660 mice treated with the solvent control.

A true comparable incidence can be obtained from the figures for the three doses of stored smoke condensate (Table 1).

\begin{tabular}{|c|c|c|c|c|}
\hline \multirow[t]{2}{*}{ Dose } & \multirow{2}{*}{$\begin{array}{l}\text { Date of } \\
\text { start of } \\
\text { experiment }\end{array}$} & \multirow{2}{*}{$\begin{array}{l}\text { Initial } \\
\text { No. of } \\
\text { animals }\end{array}$} & \multicolumn{2}{|c|}{$\begin{array}{c}\text { Tumour-bearing } \\
\text { animals }\end{array}$} \\
\hline & & & Total & Carcinom \\
\hline $\begin{array}{l}\text { Small ( } 75 \mathrm{mg} / \text { week) } \\
\text { Medium ( } 150 \mathrm{mg} / \text { week) } \\
\text { Large ( } 300 \mathrm{mg} / \text { week) }\end{array}$ & $\begin{array}{c}\text { October } \\
1962\end{array}$ & $\begin{array}{l}660 \\
660 \\
660\end{array}$ & $\begin{array}{r}5 \cdot 8 \% \\
13 \cdot 3 \% \\
32 \cdot 6 \%\end{array}$ & $\begin{array}{r}1 \cdot 1 \% \\
4 \cdot 4 \% \\
14 \cdot 9 \%\end{array}$ \\
\hline
\end{tabular}

Two subsequent experiments (to be published later) involving similar material have shown no significant alteration of carcinogenicity (Table 2) in contrast to the finding of a marked decline in carcinogenicity reported by Wynder and Hoffmann 4 .

Table 2

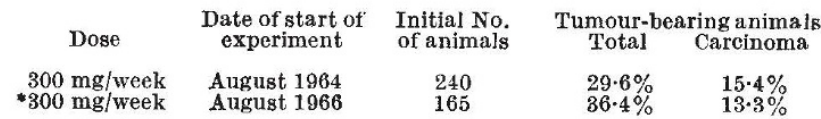

* After treatment for 92 weeks (four surviving animals).

One of the problems of using a relatively weak skin carcinogen such as tobacco smoke condensate is to maintain the animals in good health long enough to enable skin tumours to appear. It is interesting that Wynder et al..$^{2}$ varied the treatment of mice in the later stages of the experiments by painting denicotinized solutions or reducing the painting by merely treating the lesions, and not as we did, painting the whole of the back. It is possible that by altering the painting regime in this way, an even higher incidence of skin earcinomata in our series might be obtained.

R. F. Davies

T. D. DAY

Tobacco Research Council Laboratories,

Harrogate.

Received July 11, 1988.

'Passey, R. D., Nature, 218, 5149 (1968).

${ }^{2}$ Wynder, E. L., Graham, E. A., and Croninger, Adele B., Cancer Res., 13,

Day, T. D., Brit. J. Cancer, 21, 56 (1967).

- Wynder, E. L., and Hoffmann, D., Tobacco and Tobacco Smoke, 142 (Academic Press, New York, 1967)

\section{Plastids of the Venus Flytrap (Dionaea muscipula)}

Three different kinds of plastids have been observed in Venus flytrap, each in cells which perform a unique function in the plant. In the same cells, however, there are other organelles (for example, mitochondria) which are the same in all cells of the plant and similar to those in cells of most other plants. We have compared the fine structure and its relationship to the respective function of three types of plastids : the chloroplasts of the leaf cells, the plastids of the cells of the digestive gland, and the plastids of the cells of the trigger hairs.

Venus flytrap is an insectivorous flowering plant. The leaf consists of two parts, a broad petiole and a two lobed blade hinged down the middle. This blade is especially suited for trapping insects and can enclose an ant in less than $1 \mathrm{~s}$ after it has stimulated two of the three sensitive trigger hairs which are located on the surface of each lobe. After entrapment, the insect is crushed and digested during a further 7 to 10 days by the secretions from the numerous digestive glands located on the surface of each lobe ${ }^{1}$. Although the insectivorous habit is not a necessity for survival the intake of insect or protein material seems to produce more healthy plants.

Standard electron microscopic methods were used in the preparations discussed here and have already been described in detail ${ }^{2}$. The samples were fixed in glutaraldehyde/osmium tetroxide or potassium permanganate. Plants were maintained in soil sphagnum moss or grown in an incubated chamber $\left(26^{\circ} \mathrm{C}\right)$ with $14 \mathrm{~h}$ of daylight supplied by 'Gro-Lux' lamps placed 12 in. from the plants'.

Fig. 1 is an electron micrograph of a chloroplast which is representative of those observed in the photosynthetic tissue of the leaf of the flytrap. In this case, the cell was part of the laaf mesophyll tissue. The most striking feature of the chloroplasts is their complete lack of grana or of structures resembling the grana of other higher plants ${ }^{3}$. Although some thylakoids appear on occasion to form a loose association, no evidence of even rudimentary grana has been observed. The thylakoids are poorly organized, but are predominantly parallel and appear to surround the large osmiophilic globules which

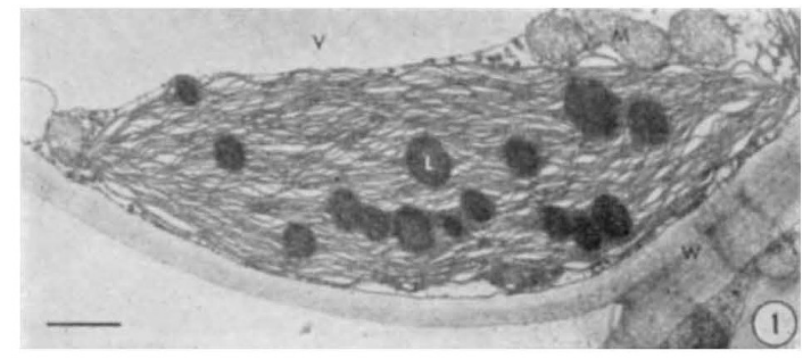

Fig. 1. Chloroplast from a flytrap eaf showing the numerous lipid globules (L) and the poorly organized thylakoids. M, Mitochondria; 